\title{
Autism Spectrum Disorder-Impact on Parenting \& Coping Strategies
}

\author{
Dr. Deepak Sharma ${ }^{1}$, Anju Joshi Sharma ${ }^{2}$
}

\section{ABSTRACT}

The purpose of this study is to determine what kind of impact the diagnosis of ASD can have on parents and what can be done to decrease the amount of stress these parents experience. Within recent decades the chances of a child being diagnosed with autism spectrum disorder has increased dramatically. Some believe this is due to the increased recognition of an autism spectrum disorder in doctors as well as parents/caregivers, teachers and other individuals that may work with children. Autism spectrum disorder (ASD) is a group of developmental disabilities that can cause significant social, communication and behavioural changes. There is no known cause and no cure for ASD. A two year old child, who appeared to be developing normally, fails to develop language, shows little interest in other people, and engages in repetitive behaviours. Parents begin a journey into the world of autism, navigating through the diagnostic process while trying to understand why their child is no longer developing normally. This paper gives a brief history of ASD, identifies the main characteristics of ASD, identifies suspected causes, explores the sense of loss and grief parents often may experience, discusses parental stress, coping strategies, the special challenges faced while parenting a child with ASD and positive personal growth parents may experience because of the child's ASD. Through parent interviews, it was evident ASD added stress to the families. It is the parent's ultimate decision on what they consider is a comfortable means of coping. There was a consensus that parents would like to talk to others who have experience in ASD - whether it is professionally or personally.

\section{Keywords: Autism Spectrum Disorder, Parenting, Coping Strategies}

The word autism is derived from the Greek word autos meaning self. According to the Oxford English Dictionary, the term was first used and defined in the 1912 American Journal of Insanity in reference to "instances where thought is divorced both from logic and from reality" (O’Brien

\footnotetext{
${ }^{1}$ Ph.D. (Psychology), India

${ }^{2}$ Ph.D. Scholar (Biotechnology) Mewar University, Rajasthan, India

*Responding Author

(C) 2016 I D Sharma, A Sharma; licensee IJIP. This is an Open Access Research distributed under the terms of the Creative Commons Attribution License (http://creativecommons.org/licenses/by/2.0), which permits unrestricted use, distribution, and reproduction in any Medium, provided the original work is properly cited.
} 


\section{Autism Spectrum Disorder-Impact on Parenting \& Coping Strategies}

\&Daggett, 2006, page 5). Autism is a lifelong neurological condition, a developmental disorder that typically occurs in the first three years of life. Autism appears as differences in development in three main areas: communication (verbal and non-verbal), social interactions and imagination, which can be seen in repetitive and restricted play or leisure activities. This is referred to as the triad of impairments. Autism is known as a 'spectrum disorder' because the severity of symptoms can range from a mild learning and social disability, to more complex needs with multiple difficulties and often very unusual behaviour. Autism results in qualitative impairments. This means that in a person with autism, skills are present (not absent) but do not develop age appropriately. Therefore different skills develop at a different pace in different people with autism. Autism is referred to as a spectrum disorder because children can have a wide range of symptoms or characteristics that affect them that range from mild to severe (Willis, 2006).The disease is found to be four times more prevalent in males than females.

India is home to about 10 million people with autism and the disability has shown an increase over the last few years. According to statistics by the Centre for Disease Control and Prevention (CDC), one in every 88 children today is born with autism spectrum disorder (ASD) against a ratio of one in 110 few years back. Although it has been described as an epidemic, ASD is neither contagious nor a disease. When looking at ASD statistics it is necessary to understand the difference between prevalence and incidence. The CDC states that prevalence indicates the number of individuals within a certain population who are diagnosed with a specific disorder; incidence refers to the number of new cases of a disorder or condition that occurs over a specific period of time, usually one year. Knowing the prevalence of a disorder allows professionals to estimate the types and amount of services a specific group will require. The prevalence of ASD has risen over the last 30 years in part due to it now being recognized in the Diagnostic Statistical Manual of Mental Disorders (DSM) as a specific disorder with established criteria. Wing (2005) suggests that the rising number of children being diagnosed with ASD is due in part to the broadening of the diagnostic criteria, development and use of standardized diagnostic instruments, and an increased awareness of the disorder. A number of standardized diagnostic instruments have been developed in the last 30 years. In order for a child to be diagnosed with autism, Frith (2003), states all three of the following symptoms must be observed in the child before age three.

1. There must be qualitative impairment in reciprocal social interactions relative to developmental level. Behavioural signs include poor use of eye gaze and of gestures; lack of personal relationships.

2. There must be a qualitative impairment in verbal and nonverbal communication relative to developmental level. Behavioural signs include delay in the acquisition of language, or lack of speech; lack of varied, spontaneous make-believe play.

3. There must be markedly restricted repertoire of activities and interests appropriate to developmental level. Behavioural signs include repetitive or stereotyped movements, such as hand flapping; interests that are abnormally intense or abnormally narrow. 


\section{Autism Spectrum Disorder-Impact on Parenting \& Coping Strategies}

When people think about ASD, most people think about the child who is affected by it. They may think about these children from that specific child's point of view and how they are perceived by others or what it would be like to not communicate effectively with others. Does anyone think about the parents of these children? The parents of children with ASD are often overlooked because everyone is focused on making the child "better." An article by McHugh, Osborne, Reed, and Saunders (2008, p. 1092) stated that, "levels of stress experienced by the parents of children with ASD are enormously high, compared to those experienced by parents of children with almost any other type of disability or health problem." Parents of children with ASD often go through an emotional rollercoaster after learning the initial diagnosis. Parents go from thinking their child is perfect, to having an incurable disorder that will affect nearly every aspect of their child's life. An expert in the field of autism (Pullen, 2009, p. 14) stated that, "many parents of children with autism have trouble coping with their own personal needs, let alone the many needs of their child with autism." There is evidence that a child with ASD can stress the marital relationship and decrease marital satisfaction (Rivers \& Stoneman, 2003).

The parents of three-year old Mohit have just heard that he has been diagnosed with ASD - this would be the initial stressor. After going through the initial shock of hearing their son's diagnosis, Mohit's parents immediately began looking for ways to make him "normal." First, they made a decision as to which early intervention program they want him to begin which added more stress because they wanted nothing but the best for their son. Early intervention programs are services provided to children with disabilities to help in the development of language, motor skills, and socialization. At the same time, their family budget had just begun getting a little tighter due to the added cost of some of Mohit's ASD treatments. Having monetary issues is an additional stressor which led to marital distress between Mohit's parents. The addition of marital stress was another stressor added to the family. Reducing the amount of stress parents experience when they have a child with ASD is important to ensure a healthy family environment. Through the interview process, parents will share information about their child's diagnosis, their emotions, what caused them stress and the ways they are coping with the stress. From this information, we will be able to examine and share ways to help these parents cope and determine helpful ways in which they can reduce the amount of stress they have experienced.

Because ASD is being diagnosed more frequently, parents need to be aware of what resources are available to them. When given appropriate resources, parents should be able to handle the diagnosis of ASD in a more effective and positive way. Special education professionals and health care professionals who have specialized in ASD should serve as a vital Support system for these families. The society we live in should also be taken into consideration when thinking of solutions to help these families that have a child with ASD. "When a child is diagnosed with a disability, you would expect society to rush in and help. But that doesn't happen," (Koegel \& LaZebnik, 2004,). There should be more people willing to learn about ASD and accept it for what it is. Along with this, people should spread awareness and advocate for ASD services to 


\section{Autism Spectrum Disorder-Impact on Parenting \& Coping Strategies}

show families affected by ASD their Support and acceptance. By taking advantage of the provided help, families of children with ASD will feel the support they need from their doctors, teachers, and the rest of the society so their whole family can be brought up in a healthy, loving and caring household. Using the information from existing research and parent surveys will make it clearer as to what kind of support families are looking for and need.

\section{Autism Spectrum Disorder (ASD)}

Autism spectrum disorder can be described as a complex developmental disorder that affects one's ability to socialize, communicate, and respond to his or her environment and is typically diagnosed before the age of three (Willis, 2006). Benson (2006, p. 685) states, "One of the most severe disabilities affecting young children is autism, a disorder that adversely affects nearly every aspect of the child's development." The word autism was first used by Leo Kanner to describe a group of children he was observing (Koegel \& LaZebnik, 2004). The word autism means "alone" and the group of children Kanner had observed had a preference to be alone (Koegel \& LaZebnik, 2004). The words "spectrum disorder" has been added onto the term "autism" because children can have a wide range of symptoms or characteristics that affect them that range from mild to severe (Willis, 2006). A parent of a child with ASD and author (Notbohm, 2005, p. xix), stated that, "No two children with autism will be completely alike. Every child will be at a different point on the spectrum."

\section{Characteristics of autism spectrum disorder}

There are many different characteristics that can be used to describe how ASD affects children. Some of these characteristics include: a delay in communication and social interaction, obsessions over specific objects, repetitive body movements, and having specific routines and rituals which they obsessively follow throughout their day (Willis, 2006). More specifically, the American Psychiatric Association's Diagnostic and Statistical Manual of Mental Disorders (2000) stated that an individual must meet at least six of the developmental and behavioral characteristics from the list before the age of three with no evidence for other conditions that are similar. This list of diagnostic criteria includes three broad developmental and behavioural areas including:-

1) Impairments in social interaction;

2) Impairments in communication; and

3) Restricted repetitive and stereotyped patterns of behaviour, interests and activities.

When diagnosing a child who shows characteristics of this complex disorder, one must decide to what extent the specific ASD characteristic affects the child so they can determine where he or she falls on the spectrum (Koegel \& LaZebnik, 2004). The diverse characteristics of ASD may have profound effects on the parents of children with ASD."Parents and clinicians agreed that communication impairment, uneven cognitive abilities, and problems in social relations were the autism-related symptoms that were most stressful for mothers and fathers of school-aged 


\section{Autism Spectrum Disorder-Impact on Parenting \& Coping Strategies}

children". (Carter \& Davis, 2008, p. 1279). In a similar article, Botts, Hoffman, Hodge, LopezWagner, Nam and Sweeney (2008, p. 155) state, "Behavioural symptoms associated with children's autism including their language and communication difficulties, cognitive impairments, reactivity to frustration, and repetitive, self-stimulatory behaviour, have been found to be related to parents' stress."

\section{Emotional Effects the Diagnosis of ASD Has on Parents}

After the initial diagnosis of ASD, parents must learn how to cope with all the changes that are occurring within their family. Davis, Rosswurm and Zane (2008,) found that, "parenting children with developmental disabilities is associated with impaired mental health, higher levels of stress, a sense of devaluation and blame, and impaired physical functioning such as tiredness or exhaustion." Experts on the treatment of autism (Koegel \& LaZebnik, 2004,) said, "Over the years, I have talked with thousands of parents of children with autism, and I can tell you that getting the news is horrific, terrifying, stressful and, depressing." After parents hear their child will no longer be developing like a typically developing child, there is no doubt they would experience a great amount of emotion.

\section{Stages of grief}

Dr. Elisabeth Kubler-Ross provided pioneering work to understand death, dying, and grief (Gibson, 2004). She then developed the five stages of grief as: denial, shock anger, bargaining/guilt, depression, and acceptance (Gibson, 2004). Parents often go through their own stages of grief after hearing their child has ASD because it is an unexpected change in their lives. Parents with disabled children present higher levels of dysphoria, intense anger, guilt, depression and anxiety (Davis, Rosswurm \& Zane, 2008). People experience the stages of grief differently because there is no sequential order in which each stage should occur and because some people may not experience some of the stages (Gibson, 2004).

\section{Depression}

Parents of children with ASD may also experience depression. In fact, depression is common in parents of children with ASD (Koegel \& LaZebnik, 2004). Ericzen, Frazee-Brookman and Stahmer (2005) reported that "Mothers of children with autism rep0l1 higher levels of depression compared to mothers of children without autism." Another author (Benson, 2006) states, "One problematic mental health outcome commonly linked to the demands of parenting a child with autism is depression." Benson (2006) also states, "The high level of depression suggests parents of children with ASD are at increased risk for poor mental health outcomes, not only because of the demands of caring for their child with ASD, but because of other stressors which may be engendered or exacerbated by their child's disorder. " The length of depression experienced by parents differs from one parent to another. "Nothing is more depressing than uncertainty and inactivity" (Koegel \& LaZebnik, 2004, p. 17).Autism spectrum disorder is full of uncertainty whether or not treatments will work and if they do, when will they begin to show results. When 


\section{Autism Spectrum Disorder-Impact on Parenting \& Coping Strategies}

parents become depressed, it is not only detrimental to themselves, but also to their family. "Depression leads to inactivity and withdrawal from society; it will damage you, your marriage, and your children" (Koegel \& LaZebnik, 2004).

\section{Stress Experienced by Parents of Children with ASD}

Many parents of children with ASD experience stress one way or another. An article by Benson (2006) stated, "Autism's impact on the family appears to be particularly severe, with parents of children with autism frequently reporting high levels of stress associated with their child's social and communicative deficits, problem behaviours, and level of dependency". Mothers and fathers of children with disabilities tend to stress about different things. Mothers tend to stress about providing appropriate care for their child, whereas fathers tend to stress about the financial toll ASD puts on their income (Koegel \& LaZebnik, 2004). Parents with children who have ASD may struggle getting through daily routines and may need to make personal sacrifices, while balancing a family life, spousal relationships and job obligations because their child was affected by ASD. That is a great deal of stress for one person to handle. Pullen (2009) reported that, "Many parents of children with autism have trouble coping with their own personal needs, let alone the many needs of their child with autism". Benson (2006) sums up his findings by saying, "Parent well-being can be both directly and indirectly affected by their child's ASD, with stressors expanding and crossing into areas of the parent's life not directly related to their child's autistic disorder."

\section{Marital stress on parents}

There is evidence that a child with ASD can stress the marital relationship and decrease marital satisfaction (Rivers \& Stoneman, 2003)."Parents of children with ASD report more symptoms of anxiety and marital dissatisfaction than parents of children with other types of disabilities" (Bedesem, Boyd \& Mancil, 2009). After hearing the initial diagnosis, parents will often times play the "blame game" in which parents go back and forth blaming each other for things that they may have done to cause their child's ASD.

\section{Coping Strategies for Parents of Children with ASD}

With all the stress of raising a child with autism, parents need ways to cope. Strategies that may be used by parents to cope may include autism support groups to hear from other parents in similar situations, reaching out for support from family and friends, taking parenting classes to learn ways to help their child grow and learn, or seeking professional help to talk about the changes happening in one's family. A study by Bedesem, Boyd and Mancil (2009) resulted in learning that the following strategies were most effective when coping with stress: social support, family support, religion, parent training, social withdrawal and professional help. A study by Hevey, Honan and Tehee (2009) reported the top facilitators of stress relief for parents included: school staff and services, respite services, family and spouses. From both studies, it is clear that both formal and informal coping strategies are important. 


\section{Autism Spectrum Disorder-Impact on Parenting \& Coping Strategies}

Ultimately, it is the parent's decision on how they choose to deal with the stress of having a child with ASD. "Parents struggling with their own emotional difficulties may have fewer coping resources and feel more stressed by their children's challenging behaviors" (Carter \& Davis, 2008, p. 1280). Similarly, no two children with ASD will be the same and no two parents are going to express the same emotions and have the same coping strategies. Hevey, Honan and Tehee (2009) stated, "Certain personality traits may be more conducive to adaptive coping than others."

\section{Support from family and friends}

Receiving support from family and friends may be the cheapest and most accessible support parents can get. As stated by an expert (Siegel, 2008) in the field of autism: Reaching out for support from your existing network is really important. Research shows maintaining the fabric of the life you had before diagnosis is more important to your longer-term well-being than forsaking it in favor of life as an autism-only mom or dad. Support from family and friends is considered to be an effective coping mechanism for dealing with the daily stress of rearing a child with autism (Bedesem, Boyd \& Mancil, 2009).

\section{Parenting classes}

Some parents find relief by taking classes to help them understand and interact with their child more effectively. "Parent education programs that teach parents naturalistic strategies to increase their child's communication have been shows to result in decrease levels of parent stress and depression" (Baker-Ericzen, Brookman-Frazee \&Stahme). Disadvantages that come with parenting classes may include availability and access of classes, paying for the classes or finding time to attend the classes.

\section{Professional help}

Willis (2006) describes what parents need after hearing their child's ASD diagnosis: "A strong support system that includes specialists such an early interventionists, special education teachers, speech pathologists, and occupational therapists." All the support systems mentioned by Willis are examples of professional help. Having this kind of support can help parents cope by meeting their emotional, practical and informational needs (Hevey, Honan \&Tehee, 2009).

\section{MATERIALS AND METHODS}

The focus of this study is on parents of children with ASD in New Delhi and how they have responded to their child's diagnosis of ASD. Therefore, the sample used in the study included five parents whom all have a child with ASD and at least one other child. Specifically, five mothers participated in the interviews. Two fathers were present during the interviews, but contributed minimally compared to the mothers. The parents were between the ages of 28 and 45 and had at least two children, one of which has ASD. The ages of the children with ASD and the amount of time that has passed since they had been diagnosed with ASD was taken into 


\section{Autism Spectrum Disorder-Impact on Parenting \& Coping Strategies}

consideration. There were no restrictions on the age and gender of the parents chosen for the sample.

\section{Data Collection}

The instrument used to gather data from the sample for this particular study was a set of Interview questions. The interview questions included items such as: general information about the child, the parent's reaction after hearing the initial diagnosis of ASD, if/how ASD has changed the parent's lives, the amount of stress (if any) that was experienced after the diagnosis, and if stress was experienced, methods that were used to cope with the stress. The interview included 38 items.

\section{Data Analysis}

The information obtained from the responses helped determine what the major causes of stress were for a parent who has a child with ASD, to what extent the stress affected parents and how parents prefer to cope with the stress. To protect the identities of the families involved, pseudonyms were used.

Table-1 Demographic Data

\begin{tabular}{|c|c|c|c|c|c|}
\hline \multirow[t]{2}{*}{ Questions } & \multicolumn{5}{|c|}{ Parent Responses } \\
\hline & $1^{\text {st }}$ & $2^{\text {nd }}$ & $3^{\text {rd }}$ & $4^{\text {th }}$ & $5^{\text {th }}$ \\
\hline Age of child & 7 & 8 & 6 & 8 & 9 \\
\hline $\begin{array}{l}\text { Age of children } \\
\text { at which } \\
\text { Diagnosed with } \\
\text { ASD }\end{array}$ & $\begin{array}{l}2 \text { Years } 8 \\
\text { Months }\end{array}$ & $\begin{array}{l}3 \text { Years } 4 \\
\text { Months }\end{array}$ & $\begin{array}{l}2 \text { Years } 11 \\
\text { months }\end{array}$ & 2 Years & 3 years \\
\hline $\begin{array}{l}\text { Age of other } \\
\text { Child }\end{array}$ & 9 Years & 4 Years & 3 Years & 11 Years & 13 Years \\
\hline $\begin{array}{l}\text { Gender of } \\
\text { Child with } \\
\text { ASD }\end{array}$ & Male & Male & Female & Male & Male \\
\hline
\end{tabular}

Table-2 Diagnosis Questions

\begin{tabular}{|c|c|c|c|c|c|}
\hline \multirow[t]{2}{*}{ Questions } & \multicolumn{5}{|c|}{ Parent Responses } \\
\hline & $\mathbf{1}^{\text {st }}$ & $2^{\text {nd }}$ & $3^{\text {rd }}$ & $4^{\text {th }}$ & $5^{\text {th }}$ \\
\hline $\begin{array}{l}\text { Did you know } \\
\text { anything about } \\
\text { ASD prior to } \\
\text { your child's } \\
\text { diagnosis }\end{array}$ & Nothing & $\begin{array}{l}\text { Knew it had } \\
\text { something to } \\
\text { do with } \\
\text { socialization }\end{array}$ & $\begin{array}{l}\text { Knew nothing, } \\
\text { but had heard } \\
\text { about it. }\end{array}$ & Yes & Not Much \\
\hline
\end{tabular}

(C) The International Journal of Indian Psychology, ISSN 2348-5396 (e)| ISSN: 2349-3429 (p) | 23 
Autism Spectrum Disorder-Impact on Parenting \& Coping Strategies

\begin{tabular}{|c|c|c|c|c|c|}
\hline \multirow[t]{2}{*}{ Questions } & \multicolumn{5}{|c|}{ Parent Responses } \\
\hline & $1^{\text {st }}$ & $2^{\text {nd }}$ & $3^{\text {rd }}$ & $4^{\text {th }}$ & $5^{\text {th }}$ \\
\hline $\begin{array}{l}\text { Did You go } \\
\text { through the } \\
\text { stages of grief? }\end{array}$ & $\begin{array}{l}\text { Yes - } \\
\text { shock, } \\
\text { guilt, } \\
\text { anger }\end{array}$ & $\begin{array}{l}\text { Yes- denial, } \\
\text { guilt, anger }\end{array}$ & $\begin{array}{l}\text { Yes - shock } \\
\text { denial, guilt, } \\
\text { anger \& } \\
\text { depression }\end{array}$ & $\begin{array}{l}\text { Yes - shock! } \\
\text { Denial, anger } \\
\& \\
\text { acceptance. }\end{array}$ & $\begin{array}{l}\text { Yes- } \\
\text { Depression, } \\
\text { Shock \&Guilt }\end{array}$ \\
\hline $\begin{array}{l}\text { Do you feel } \\
\text { anything } \\
\text { positive came } \\
\text { out of hearing } \\
\text { your child's } \\
\text { diagnosis }\end{array}$ & No & No & No & Yes & No \\
\hline $\begin{array}{l}\text { What was the } \\
\text { worst part of } \\
\text { hearing your } \\
\text { child's diagnosis }\end{array}$ & $\begin{array}{l}\text { God has } \\
\text { punished } \\
\text { us for } \\
\text { our faults } \\
\text { in this } \\
\text { way }\end{array}$ & $\begin{array}{l}\text { Knowing } \\
\text { that he may } \\
\text { not do things } \\
\text { that other } \\
\text { children } \\
\text { would do }\end{array}$ & $\begin{array}{l}\text { Knowing he } \\
\text { would not have } \\
\text { a normal life. }\end{array}$ & $\begin{array}{l}\text { Knowing } \\
\text { their child is } \\
\text { one of36 } \\
\text { grandchildren } \\
\text { with special } \\
\text { needs }\end{array}$ & $\begin{array}{l}\text { Who will take } \\
\text { care of him } \\
\text { after us }\end{array}$ \\
\hline $\begin{array}{l}\text { When did you } \\
\text { realize your } \\
\text { child may not be } \\
\text { developing } \\
\text { typically }\end{array}$ & $\begin{array}{l}1 \text { Year } 2 \\
\text { months. } \\
\text { He was } \\
\text { not } \\
\text { talking }\end{array}$ & $\begin{array}{l}2 \text { Years } 9 \\
\text { months. } \\
\text { Did not } \\
\text { communicate } \\
\text { with us }\end{array}$ & $\begin{array}{l}2 \text { Years. Doctor } \\
\text { realized she } \\
\text { was not } \\
\text { reaching his } \\
\text { developmental } \\
\text { benchmarks. B }\end{array}$ & $\begin{array}{l}1 \text { Year } 4 \\
\text { months. } \\
\text { began to flap } \\
\text { hands \& did } \\
\text { things } \\
\text { repetitively }\end{array}$ & $\begin{array}{l}2 \text { Years } 7 \\
\text { Months. Doctor } \\
\text { suspected } \\
\text { something, but } \\
\text { didn't know } \\
\text { what. }\end{array}$ \\
\hline
\end{tabular}

Table-3 Life after Diagnosis

\begin{tabular}{|c|c|c|c|c|c|}
\hline \multirow[t]{2}{*}{ Questions } & \multicolumn{5}{|c|}{ Parent responses } \\
\hline & $1^{\text {st }}$ & $2^{\text {nd }}$ & $3^{\text {rd }}$ & $4^{\text {th }}$ & $5^{\text {th }}$ \\
\hline $\begin{array}{l}\text { How do your } \\
\text { other children } \\
\text { currently feel } \\
\text { about their } \\
\text { sibling with } \\
\text { ASD }\end{array}$ & $\begin{array}{l}\text { He is just her } \\
\text { brother, she } \\
\text { doesn't know } \\
\text { anything } \\
\text { different. }\end{array}$ & $\begin{array}{l}\text { He is too } \\
\text { young to } \\
\text { understand. }\end{array}$ & $\begin{array}{ll}\mathrm{He} \text { is too } \\
\text { young to } \\
\text { understand }\end{array}$ & $\begin{array}{l}\text { She is } \\
\text { protective for } \\
\text { him }\end{array}$ & $\begin{array}{l}\text { He is more } \\
\text { nurturing for } \\
\text { him }\end{array}$ \\
\hline $\begin{array}{l}\text { What was the } \\
\text { first kind of } \\
\text { treatment } \\
\text { your child } \\
\text { received }\end{array}$ & $\begin{array}{l}\text { Early } \\
\text { Childhood } \\
\text { program. }\end{array}$ & Nothing & $\begin{array}{l}\text { Training in a } \\
\text { special school }\end{array}$ & $\begin{array}{l}\text { Early } \\
\text { Childhood } \\
\text { program. }\end{array}$ & $\begin{array}{l}\text { Training in a } \\
\text { special school }\end{array}$ \\
\hline
\end{tabular}


Autism Spectrum Disorder-Impact on Parenting \& Coping Strategies

\begin{tabular}{|c|c|c|c|c|c|}
\hline \multirow[t]{2}{*}{ Questions } & \multicolumn{5}{|c|}{ Parent responses } \\
\hline & $1^{\text {st }}$ & $2^{\text {nd }}$ & $3^{\text {rd }}$ & $4^{\text {th }}$ & $5^{\text {th }}$ \\
\hline $\begin{array}{l}\text { Did your } \\
\text { parenting } \\
\text { ways change } \\
\text { after you } \\
\text { learned your } \\
\text { child had } \\
\text { ASD? If so, } \\
\text { how? }\end{array}$ & $\begin{array}{l}\text { Yes, they } \\
\text { changed the } \\
\text { way they } \\
\text { interacted } \\
\text { with him }\end{array}$ & $\begin{array}{l}\text { Not really, } \\
\text { just looked at } \\
\text { ways to } \\
\text { handle his } \\
\text { self-esteem }\end{array}$ & $\begin{array}{l}\text { Yes, they } \\
\text { changed the } \\
\text { way they } \\
\text { communicated } \\
\text { with him }\end{array}$ & $\begin{array}{l}\text { Yes, } \\
\text { motivated us } \\
\text { for } \\
\text { acceptance. }\end{array}$ & $\begin{array}{l}\text { Yes, they } \\
\text { changed the } \\
\text { way they } \\
\text { communicated } \\
\text { with him as } \\
\text { well as their } \\
\text { environment }\end{array}$ \\
\hline
\end{tabular}

Table-4 Current Living Situation of the families

\begin{tabular}{|c|c|c|c|c|c|}
\hline \multirow[t]{2}{*}{ Questions } & \multicolumn{5}{|c|}{ Parent Responses } \\
\hline & $1^{\text {st }}$ & $2^{\text {nd }}$ & $3^{\text {rd }}$ & $4^{\text {th }}$ & $5^{\text {th }}$ \\
\hline $\begin{array}{l}\text { Has ASD affected your } \\
\text { family financially }\end{array}$ & Yes & Yes & Yes & No & Yes \\
\hline $\begin{array}{l}\text { Do you and your spouse } \\
\text { work? }\end{array}$ & Yes & No & No & Yes & No \\
\hline $\begin{array}{l}\text { Has your child's ASD } \\
\text { affected your relationship } \\
\text { with your } \\
\text { Spouse }\end{array}$ & Yes & No & Yes & No & Yes \\
\hline $\begin{array}{l}\text { In what ways has ASD } \\
\text { affected you? }\end{array}$ & $\begin{array}{l}\text { Mentally, } \\
\text { Physically }\end{array}$ & $\begin{array}{l}\text { Mentally, } \\
\text { Physically, } \\
\text { Economically }\end{array}$ & $\begin{array}{l}\text { Emotionally, } \\
\text { Economically, } \\
\text { Mentally }\end{array}$ & $\begin{array}{l}\text { Emotionally, } \\
\text { Mentally }\end{array}$ & $\begin{array}{l}\text { Emotionally } \\
\text {,Physically } \\
\text { Economically }\end{array}$ \\
\hline $\begin{array}{l}\text { Did ASD make your life } \\
\text { more stressful? } \\
\text { Parent }\end{array}$ & Yes & Yes & Yes & Yes & Yes \\
\hline $\begin{array}{l}\text { What has ASD taught you } \\
\text { as a parent? As a member } \\
\text { of our society? }\end{array}$ & $\begin{array}{l}\text { Patience, } \\
\text { tolerance } \\
\text { of others }\end{array}$ & $\begin{array}{l}\text { Parents of } \\
\text { children with } \\
\text { special needs } \\
\text { are very } \\
\text { involved with } \\
\text { their child's } \\
\text { School }\end{array}$ & $\begin{array}{l}\text { Acceptance of } \\
\text { other children } \\
\text { with special } \\
\text { needs. }\end{array}$ & $\begin{array}{l}\text { Understand } \\
\text { ing of those } \\
\text { who are } \\
\text { different. }\end{array}$ & Patience \\
\hline $\begin{array}{l}\text { What is one thing you } \\
\text { wished everyone knew } \\
\text { about ASD }\end{array}$ & $\begin{array}{l}\text { Individuals } \\
\text { with } \\
\text { autism are } \\
\text { not } \\
\text { unloving } \\
\text { or lacking } \\
\text { in emotion } \\
\text { and } \\
\text { empathy. }\end{array}$ & $\begin{array}{l}\text { A child with } \\
\text { ASD is first } \\
\text { and foremost } \\
\text { a child }\end{array}$ & $\begin{array}{l}\text { It is a } \\
\text { disability and } \\
\text { not a disease. }\end{array}$ & $\begin{array}{l}\text { To not be } \\
\text { afraid to ask } \\
\text { questions }\end{array}$ & $\begin{array}{l}\text { Families of } \\
\text { children with } \\
\text { autism don't } \\
\text { want pity - } \\
\text { we need } \\
\text { compassion. }\end{array}$ \\
\hline
\end{tabular}


Autism Spectrum Disorder-Impact on Parenting \& Coping Strategies

Table-5 Child with ASD

\begin{tabular}{|c|c|c|c|c|c|}
\hline \multirow[t]{2}{*}{ Questions } & \multicolumn{5}{|c|}{ Parent responses } \\
\hline & $1^{\text {st }}$ & $2^{\text {nd }}$ & $3^{\text {rd }}$ & $4^{\text {th }}$ & $5^{\text {th }}$ \\
\hline $\begin{array}{l}\text { What do you } \\
\text { feel your } \\
\text { child's } \\
\text { weaknesses }\end{array}$ & $\begin{array}{l}\text { Communication, } \\
\text { short attention } \\
\text { span \& not } \\
\text { being social }\end{array}$ & $\begin{array}{l}\text { Being } \\
\text { impulsive, } \\
\text { constant } \\
\text { talking \& } \\
\text { being short } \\
\text { tempered }\end{array}$ & $\begin{array}{l}\text { Communication, } \\
\text { learning slowly } \\
\text { \& understanding } \\
\text { emotions. }\end{array}$ & $\begin{array}{l}\text { Difficulty } \\
\text { expressing } \\
\text { empathy in } \\
\text { ways } \\
\text { that others } \\
\text { expect or } \\
\text { understand }\end{array}$ & $\begin{array}{l}\text { Thinking } \\
\text { about things } \\
\text { more } \\
\text { generally or } \\
\text { that aren't in } \\
\text { the here and } \\
\text { now }\end{array}$ \\
\hline $\begin{array}{l}\text { What is your } \\
\text { child's } \\
\text { emotional } \\
\text { makeup like }\end{array}$ & Usually calm & $\begin{array}{l}\text { Very happy } \\
\text { unless he is } \\
\text { told no and } \\
\text { can be } \\
\text { easily } \\
\text { frustrated. }\end{array}$ & $\begin{array}{l}\text { she might lack, } \\
\text { or seem to lack, } \\
\text { empathy with } \\
\text { others }\end{array}$ & $\begin{array}{l}\text { Rarely } \\
\text { shows any } \\
\text { emotions. }\end{array}$ & $\begin{array}{l}\text { Usually calm, } \\
\text { less } \\
\text { something } \\
\text { sets him off }\end{array}$ \\
\hline $\begin{array}{l}\text { What is the } \\
\text { biggest } \\
\text { improvement } \\
\text { your child } \\
\text { has made } \\
\text { since a } \\
\text { diagnosis has } \\
\text { been made }\end{array}$ & $\begin{array}{l}\text { Writing skills, } \\
\text { Less concern for } \\
\text { what others may } \\
\text { think of them }\end{array}$ & $\begin{array}{l}\text { Speech, } \\
\text { eating } \\
\text { habits, self- } \\
\text { stims has } \\
\text { ended }\end{array}$ & $\begin{array}{l}\text { Loyalty, } \\
\text { Honesty }\end{array}$ & $\begin{array}{l}\text { Non- } \\
\text { judgemental } \\
\text { listening }\end{array}$ & $\begin{array}{l}\text { Cognitive } \\
\text { skills are } \\
\text { improving \& } \\
\text { he knows his } \\
\text { personal } \\
\text { information. }\end{array}$ \\
\hline $\begin{array}{l}\text { What are } \\
\text { your dreams } \\
\text { and } \\
\text { aspirations } \\
\text { for your } \\
\text { child }\end{array}$ & $\begin{array}{l}\text { Hopes he } \\
\text { becomes } \\
\text { independent and } \\
\text { successful in } \\
\text { whatever he } \\
\text { does }\end{array}$ & $\begin{array}{l}\text { That he has } \\
\text { exploded } \\
\text { through any } \\
\text { and all } \\
\text { perceived } \\
\text { limitations } \\
\text { since the } \\
\text { day that she } \\
\text { was born. }\end{array}$ & $\begin{array}{l}\text { Hopes she will } \\
\text { have true } \\
\text { friends and } \\
\text { become } \\
\text { independent }\end{array}$ & $\begin{array}{l}\text { That he is } \\
\text { HAPPY. } \\
\text { God, please, } \\
\text { just let him } \\
\text { be HAPPY. }\end{array}$ & $\begin{array}{l}\text { Hopes he will } \\
\text { live } \\
\text { independently } \\
\text { and as normal } \\
\text { as he can and } \\
\text { have friends. }\end{array}$ \\
\hline
\end{tabular}

\section{CONCLUSION}

This Paper clearly illustrates how ASD affects the lives of parents. Each part of the parent interview added to the bigger picture of the impact ASD has on parents. In addition, clear Representations of the parent's responses to pertinent interview questions were defined through Brief summaries of how the parents responded as well as through the use of tables. Having a child with ASD is a life altering. It can change how parents identify themselves, determine 


\section{Autism Spectrum Disorder-Impact on Parenting \& Coping Strategies}

where and when they are able to go places, affect their friendships, change their social life, and affect career decisions. It alters relationships with partners or spouses and affects siblings. Every parent reacts differently to their child's diagnosis of ASD. All parents go through an "adjustment" period where they are unsure of exactly what their child having ASD indicates for the child's and their future. Parents must strike a balance between doing what is best for their child while also creating a sense of normalcy for others in the family.

Parents are faced with an ambiguous loss when a child is diagnosed with ASD. There is no closure and each day brings new challenges for parents. Boss (1999), says it well when she states: “Ambiguous loss is the most devastating because it remains unclear, indeterminate”

\section{DISCUSSION}

\section{Challenges When Parenting a Child with ASD}

Parents consistently stated that social support was crucial to coping with their child's ASD. Ironically, social support is often lost due to the behaviours exhibited by a child. Society's intolerance combined with the parent's feelings of being judged as poor parents often caused parents to withdraw from activities outside the home. Parents identify four characteristics related to the child's ASD that make parenting particularly challenging:

1. The child's unpredictable, inappropriate and destructive behaviours.

2. The child's need for sameness and routine.

3. Difficulties relating to the child's ability to process sensory stimuli.

4. The child's inability to communicate and lack of emotional bonding

Finding childcare for a child with ASD can be challenging. The more severe the Behaviours the child exhibits, the less likely the parents are to find someone willing to take on the childcare challenge (Stillman, 2005). Parents, particularly mothers, may be unable to return to work because childcare centers refuse to take the child. Although facilities may not have a specific policy in regards to ASD children, they will want to meet the child and observe him in the day care setting before agreeing to allow the child to attend. A child's behaviours related to having ASD can cause the greatest amount of anxiety and distress for parents. When the child's behaviours are unacceptable to friends and extended family members parents feel inadequate and feel they are judged to be poor parents

\section{Coping Strategies Used by Parents}

Just as each child with ASD is unique, so too is each parent's response to the ASD diagnosis. Parents coping strategies may be affected by a number of factors including: religious beliefs, level of education, financial status, cultural norms, and living in a rural vs. urban area. Resolved parents are able to put aside questions of causation, accept the child's abilities and limitations, and look at the benefits in the situation while still acknowledging the difficulties they face. Unresolved parents, especially, feel the child's diagnosis has produces negative feelings about 


\section{Autism Spectrum Disorder-Impact on Parenting \& Coping Strategies}

one's abilities as a parent, and have a negative view of their prospects for the future. Milshtein et al. (2009) observed parents falling into one of three categories: feeling oriented, action oriented, or thinking oriented. In the feeling oriented group parents found that talking about their feelings openly relieved the stress and they took comfort in the emotional support they received from friends and family. Action oriented parents were interested in finding answers and taking charge. Thinking oriented parents focused on finding more information related to working through problems; they became active in support groups, had a realistic attitude toward their child's abilities, and were strong advocates for their child.

Obrien and Daggett (2006) describe three ways parents respond emotionally when their child is diagnosed with an ASD: (a) focus on what might have been; (b) focus on what could be; (c) focus on what is.

Parents, especially mothers, may have to re-evaluate career goals due to their child having ASD. Parents found that by placing less emphasis on career and more emphasis on parenting and family they had a greater ability to enjoy life and felt less stress related to parenting a child with ASD (Tunali\& Powers, 2002). Families who demonstrated resilience had a greater ability to cope with their child's ASD. Resilience is the capacity to endure adversity while becoming stronger and more resourceful as a result. It took, on average, two years from the time of initial diagnosis of the child's ASD until a family felt they had adjusted to the demands and changes related to parenting the child. Parents who utilized social support, positive reframing, emotional regulation, and compromise coping skills reported having a positive daily mood, less stress, and fewer feelings of depression. Parents who chose blaming, worrying, and withdrawal as coping strategies reported a negative outlook, higher levels of daily stress, and increased feelings of depression and sadness. Problem-focused coping was found to both positively and negatively affect daily mood. This may be due in part because many of the challenges parents face related to their child's ASD are not able to be changed.

How parents cope with the diagnosis and emotional issues varies, but consistently parents report a strong social support network is a necessary part of being able to cope (Gray, 2006, Altiere \& Von Kluge, 2009,) Parents who were involved in support groups, had a strong sense of faith and spirituality, and a supportive extended family rated felt better able to cope and also reported having a higher degree of satisfaction with their lives.

Before being diagnosed with ASD, all of the parents described different situations that made them think their child was not developing typically. Parents began to notice their children were developing differently between the ages of a year and a year and a half. After hearing the diagnosis, the parents felt many different emotions. Though it gave some parents a sense of relief, hearing the official diagnosis was inevitably depressing. Two of the parents felt sadness when they thought about their child not being able to live a normal life. 


\section{Autism Spectrum Disorder-Impact on Parenting \& Coping Strategies}

The interviewed parents were asked to describe their experiences of going through the stages of grief. All of the parents did not go through all the stages of grief nor did the parents experience the stages of grief in the same order.

All parents experienced shock and anger. These two emotions can be closely related because parents were shocked to find out something was wrong with their child and then angry because they wondered why this would happen to their child. After coming to terms with diagnosis, the two parents who accepted the diagnosis felt as though their child was just their child and they were not going to let a label take that away from them. The parent who has yet to accept the ASD diagnosis found herself researching ASD to find ways to help her son.

After hearing the diagnosis of their child, two out of three of the parents claimed to have made changes in their life. They acknowledged making changes to the way they interacted and communicated with their child with intentions of their child learning from their actions. One mother said they had changed their environment to make it less cluttered, safer and more child friendly. There was one parent who said they did not many any significant changes within their household.

Negative coping through withdrawal, escape, blaming, and feeling helpless were used more by mothers then fathers (Pottie \& Ingram, 2008). Fathers reported that it was difficult for them to maintain personal friendships and felt this led to their feeling depressed (Teehee, Honan, \& Hevy, 2009). However it should also be noted that fathers did not view the child's ASD as being as life changing as mothers did (Milshtein et al., 2009).

As awareness of ASD increases, hopefully society will take a more compassionate look at the child and the parents, be more accepting and willing to accommodate, and not so quick to judge the parents by the child's behaviours.

\section{RECOMMENDATIONS}

Researching information about different coping strategies within the literature review as well as interviewing parents about their preferred coping strategy proved that all parents cope with their stress in different ways. In the end, it is the parent's ultimate decision on what they consider is a comfortable means of coping. From the parent interviews, it was apparent there was a need for some sort of coping strategies. There was a consensus that parents would like to talk to others who have experience in ASD - whether it is professionally or personally. With this information established, parents of children with ASD need better access to support groups and professional help. The next logical step is to establish contacts to make these ideal coping strategies accessible to all families in need. From there, parents would be able to take advantage of speaking with others who have experience with ASD. 


\section{Autism Spectrum Disorder-Impact on Parenting \& Coping Strategies}

\section{REFERENCES}

American Psychiatric Association. (2000). American psychiatric association's diagnostic and statistical manual o/mental disorders (4/11 ed.). Washington, DC: American Psychiatric Association.

Autism speaks. (2010). Facts about autism. Retrieved from: www.autismspeaks.org

Baker-Ericzen, M., Brookman-Frazee, K., \& Stahmer, A. (2005, April). Stress levels and adaptability in parents of toddlers with and without autism spectrum disorders. Research \& Practice/or Persons with Severe Disabilities, 30 (4),194-204. Retrieved from: http://ezproxy.lib.uwstout.edu:2170/ehost/pdf?vid=5\&hid=112\&sid=231594c692cc4e74-9f58-66d499f131c2\%40sessionmgr112

Benson, P. (2006, July). The impact of child symptom severity on depressed mood among parents of children with ASD: The mediating role of stress proliferation. Journal of Autism and Developmental Disorders, 36 (5),685-695. Retrieved from: http://ezproxy.lib.uwstout.edu:2113/hww/results/getResuits.jhtml?

_DARGS=/hww/result slresults_common.jhtml.33

Centers for Disease Control and Prevention.(2010). Autism spectrum disorders. Retrieved from: www.cdc.gov/ncbddd/autismiindex.htmi

Davis, c., Rosswurm, M., \& Zane, T, (2008, April).The cost of fad treatments in autism. Journal of Early and Intensive Behavior Intervention, 5 (2), 44-51. Retrieved from: http://web.ebscohost.com/ehost/pdfviewer/pdfviewer?vid=2\&hid=9\&sid=6b559c7088c149a3-97 ea-27faadb5580a\%40sessionmgr12

Gibson, L. (2004, July). Good grief: Moving from grief to comic relief. Urologic Nursing, 24 (5),446-447. Retrieved from: http://ezproxy.lib.uwstout.edu:2170/ehost/pdf?vid=8\&hid= 12\&sid=3486094a-41 d8-4fc7-80fl-a9b4c5545c60\%40sessionmgrl2

Koegel, L., \&LaZebnik, C. (2004).Overcoming autism. New York, NY: Penguin Group.

McHugh, L., Osborne, L., Reed, P., \& Saunders, 1.(2008, July). Parenting stress reduces the effectiveness of early teaching interventions for autistic spectrum disorders. Journal of Autism and Developmental Disorder, 38 (6), 1092-1103. Retrieved from: http://ezproxy.lib.uwstout.edu:2113/hww/results/external_link_maincontentframe.jhtml?

_DARGS=/hww/results/results _ common.jhtm1.42

Naseef, R. (2001). Special children, challenged parents. Baltimore, MD: Paul H. Brookes Publishing Co.

Notbohm, E. (2005). Ten things every child; pith autism wishes you knew. Arlington, TX: Future Horizons, Inc

Taylor, B.B. (2006). Vaccines and the changing epidemiology of autism. Child: Care, Health \& Developmen,. 32(5), 511-519. doi:10.111/j.1365.2006.00655.x

Tehee, E., Honan, R. \& Hevy, D. (2009) Factors contributing to stress in parents of individuals with autistic spectrum disorders. Journal of Applied Research in Intellectual Disabilities, 22, 34-42. Retrieved from EBSCO host. 


\section{Autism Spectrum Disorder-Impact on Parenting \& Coping Strategies}

Wiggins, L.D., Robins, D.L., Bakeman, R., \& Adamson, B.L. (2009). Brief report: Sensory abnormalities as distinguishing symptoms of autism spectrum disorders in young children. Journal of Autism and Developmental Disorders, 39(7), 1087-1091. Retrieved from EBSCO host

Wing, L. (2001).The autism spectrum. Berkley, CA: Ulysses Press.

Wing, L. (2005). Reflections on opening Pandora's box. Journal of Autism and Developmental Disorders, 35(2), 197-202. doi: 10.1007/s10803-1998-2.

World Health Organization (1992). International classification of diseases: Diagnostic criteria for research (10th ed.). Geneva, Switzerland.

How to cite this article: D Sharma, A Sharma (2016), Autism Spectrum Disorder-Impact on Parenting \& Coping Strategies, International Journal of Indian Psychology, Volume 3, Issue 4, No. 56, ISSN 2348-5396 (e) | ISSN: 2349-3429 (p), DIP: 18.01.003/20160304, ISBN: 978-1365-23992-2 